\title{
EMPLOYEE CAREER DEVELOPMENT: A STUDY ON CAREER MANAGEMENT, COMPETENCE, SATISFACTION AND ORGANIZATIONAL COMMITMENT IN A STAR HOTEL OF BALI
}

\author{
Suwandana I Gusti Made \\ Management Program, University of Udayana, Bali, Indonesia \\ E-mail: gungdesuwandana@unud.ac.id
}

\begin{abstract}
Important factors to ensure the success and survival of an organization are human resources who are reliable, capable, skilled and have high morale, especially in the face of global competition and free markets. Quality and service improvement from human resources is by human resource development program, in which there are work technical improvement programs and employee career planning and development. The company has an obligation to help its employees realize their abilities and by integrating individual careers with the company they will benefit. For employees, clear benefits are satisfaction, personal development, and a quality work life.
\end{abstract}

\section{KEY WORDS}

Career management, competence, satisfaction, organizational commitment.

Two things that underlie career development are work performance and work experience. An employee's work performance can be measured through an assessment whose assessment is adjusted to the conditions of the company and should be carried out routinely in a certain period. Identification obtained from the results of the employee's assessment can be classified into the category of very good, good, bad and very bad which will determine the opportunities for employees to develop their careers in accordance with the career path in the organization. Every employee who is assessed will know his ability through the employee's work value. This assessment will support skills and speed in completing employee tasks, so the error rate will decrease. Employee working period usually indicates the employee's work journey, the longer the working period, the more work experience that is owned by an employee, so that the more skilled and the faster the employee completes the task for which he is responsible.

Every employee always expects to be able to occupy a certain position higher than a certain period of time. Career and employee positions can reflect the quality of the employees concerned, which is required to be able to master various knowledge, abilities, skills and experience. Careers are social constructs that are formed by an ongoing process of self-creation, the development of forms and an increase in self-worth (Millward and Kyriakidou, 2004). Therefore the problem of career planning and development in the organization becomes very large, where as good as any career planning by employees without systematic and programmatic career development will be very impossible to achieve in an organization.

According to Nazli (2007), careers must start from the beginning with the support of superiors or mentors and support from the environment both the family environment and the work environment is very helpful for career development. Agarwala (2008) states that skills, competencies and abilities are very important factors that influence individual career choices. Whereas Veldhoven and Dorenbosch (2008) view age and proactive roles as having an important meaning in developing one's career.

Career satisfaction refers to the level of individual affective orientation towards his career (juang \& Klein, 2000). Interest in career satisfaction is intensified by results or behavioral consequences of career satisfaction, such as commitment and desire to leave (Igbaria, Greenhaus, \& Parasuraman, 1991). Satisfaction in employees is usually associated with the same structure used to motivate. Expectation theory states that people seek 
satisfaction based on their perceptions, attitudes, and beliefs, in order to get desired results that can strengthen or enhance pleasure and avoid difficulties or suffering (Vroom, 1964). Furthermore Vroom (1964), stated that including characteristics or organizational aspects that increase satisfaction are opportunities to progress and tasks related to work that can be enjoyed. Hsu, et al (2003), states that career level models are used to describe a person's career progress which includes opportunities for progress, roles, and tasks that accommodate such progress. Thus a career level model rooted in Super (1957), provides a descriptive framework for examining the satisfaction of work progress. According to Super's theory (1957), that individuals normally move through different levels of work during the course of their career life cycles.

According to Orpen (1994) career management is a policy or rule that is compiled and developed by an organization to improve the career effectiveness of its employees. Career management carried out by the organization as an employee career development activity that aims to increase work productivity. Employees who need self-development will try to reach a position through certain channels by improving the performance of each individual. Apart from the organization, employees also need to conduct career management individually through planning and tactics. Career planning and tactics will help employees achieve certain careers that are tailored to the provision of career paths in the company.

Career development is described as an interactive development of internal career identity formation and significant growth of external careers (Hoekstra, 2010). Career development is an effective way to acquire and develop staff, which is crucial for the role and effectiveness of career management in the hospitality industry. Career development is also felt to be able to gain the development of individual abilities by working in harmony with efforts to improve employee career competencies. Career development is influenced by career motives, work performance and career roles (Hoekstra, 2010). Whereas Kong (2011) argues that career development is influenced by career competencies, hotel career management and career commitment.

\section{LITERATURE REVIEW}

Career according to Simamora (2004) is divided into two perspectives namely subjective and objective. Careers viewed from the subjective side are careers that consist of changes in values, attitudes and motivations that occur because someone is getting older. Whereas from an objective perspective, a career is a sequence occupied by a person during his lifetime. Both perspectives are focused on individuals, who assume that people have some degree of control over their destiny, so they can change opportunities to maximize success and satisfaction that comes from their careers.

Effective career management will carry out career development by increasing employee career competencies with the results of increasing employee satisfaction will be achieved later. In today's business or business environment, organizations play an important role in career management systems (Baruch, 2006). As in the tourism industry, hotels can provide effective career management activities such as training, mentoring, performance appraisal and development programs for employees (Kong, 2011). With regard to career satisfaction, career management has various practical activities such as job rotation schemes (Campion, 1994), sponsorship and training careers (Greenhaus, 1990) and performance appraisal (Burke, 2001).

Competence is also defined as the ability to carry out a task, obligation or role, the ability to integrate knowledge, skills, attitudes, personal values, and the ability to build knowledge and skills through experience and learning conducted (Warta Warga, 2009). Kong (2011) stated that an increase in employee career competence requires a good cooperative relationship between managers and employees themselves. So the role and interrelation between management and employees will have a positive impact on the development and improvement of employee competencies.

Career development is closely related to career planning and career management. An understanding of career development in an organization requires an examination of two 
processes, including how to plan a career and set career goals and how organizations design and implement career development programs. According to Greenhaus (2010) career development is an ongoing process of individual development through the career stages of an employee. It was also said that career development helps employees in developing tasks, formulating goals and strategies in their careers and lives.

Career development relationships with career satisfaction cannot be separated from the company's efforts to pay attention to the needs of employees themselves. Greenhaus (1990) says that career satisfaction is individual satisfaction that encourages intrinsic and extrinsic aspects of his career, including salary, benefits and opportunities to develop. Employees with the availability of a significant career development program in the company will well demonstrate an increase in job satisfaction and loyalty to the company, which affects the decline in employee turnover rates within the company (Jackson, 2009). The same thing is said by Carson et al (1996), that employees who are satisfied with their careers currently have a high commitment to the company, and will strongly support all new strategies made by the company (Gaertner, 1989). In other words, the higher career satisfaction will create a stronger desire to continue working in a company (Igbaria, 1991).

Employee commitment to the organization has now received much attention in the literature on organizational behavior, especially related to job satisfaction. This is because, job satisfaction is closely related to employee behavior towards their work, organizational commitment is an attitude of employee partiality towards the organization, which is an important behavioral dimension that can be used to measure and evaluate employee strengths in defending and carrying out their duties and obligations in an organization, so that a strong relationship between job satisfaction and organizational commitment has been found through various studies (Luthan, 2005). By knowing the commitment that employees have, the organization can determine the direction of its policies through strong and efficient human capital, so as to create strong competitiveness in the face of increasingly sharp competition.

Hypothesis:

- H1: Career management effect employee career development in star hotels in Bali;

- H2: Career competence effect employee career development in star hotels in Bali;

- H3: employee career development effect employee career satisfaction in star hotels in Bali;

- H4: Employee career satisfaction effect organizational commitment in star hotels in Bali.

\section{METHODS OF RESEARCH}

The population of this study is all permanent employees of hotels who have a level or have starred standards in Badung Regency. What is meant by star hotels are hotels that have standard star product and service facilities, namely 2 stars, 3 stars, 4 stars and 5 stars. The total population in this study is 100 star hotels.

The sample in this study is permanent employees at Star Hotels in Badung Regency. The sample in this study was taken from all starred hotels in Badung Regency, amounting to 100 star hotels, where the samples were taken by two permanent employees from each hotel, so the number of samples obtained was 200 according to the characteristics of the sample. The reason for choosing permanent employees in each hotel as a sample in this study was due to the opportunity for permanent employees to be able to develop a career better compared to non-permanent employees. More specifically, this study aims to gather information about career management, career competence, career development, career satisfaction and organizational commitment.

The sampling method in this study was using the Accidental Sampling method, where in each starred hotel a random sample of permanent employees will be taken according to the characteristics of a sample of 2 employees from 100 star hotels in Badung Regency. So that later a good sample will be obtained and have the same sample characteristics in different hotels. 
The data analysis technique in this study uses PLS (partial least square), as an alternative in the theoretical basis on the design of weak models and or the available indicators do not meet the reflexive measurement model. (Solimun, 2010). PLS is a powerful analytical method because it can be applied to all data scales, does not require many assumptions and the sample size does not have to be large. PLS can be used as a confirmation of theory, it can also be used to build relationships that have no basis for the theory to know whether to test propositions.

\section{RESULTS AND DISCUSSION}

Testing the hypothesis based on the results of the Path Coefficients (Mean, STDEV, TValues) results in the following table:

Table 1 - Path Coefficients Result

\begin{tabular}{|l|c|c|c|c|}
\hline \multicolumn{1}{|c|}{ Correlation } & $\begin{array}{c}\text { Original Sample } \\
(\mathrm{O})\end{array}$ & $\begin{array}{c}\text { Sample Mean } \\
(\mathrm{M})\end{array}$ & $\begin{array}{c}\text { Standard Deviation } \\
(\mathrm{STDEV})\end{array}$ & $\begin{array}{c}\text { Standard Error } \\
(\mathrm{STERR})\end{array}$ \\
\hline Career Satisfaction -> Org. Commitment & 0.804305 & 0.800352 & 0.041088 & 0.041088 \\
\hline Career Competence -> Career Satisfaction & 0.117697 & 0.123853 & 0.200426 & 0.200426 \\
\hline Career Competence -> Career dev. & 0.829215 & 0.821422 & 0.046260 & 0.046260 \\
\hline Career manag. -> Career Satisfaction & -0.006629 & -0.002532 & 0.086835 & 0.086835 \\
\hline Career manag. -> Career dev. & 0.113833 & 0.119775 & 0.060358 & 0.060358 \\
\hline Career dev. -> Career satisfaction & 0.678646 & 0.659471 & 0.213188 & 0.213188 \\
\hline
\end{tabular}

Primary Data, 2017

Hypothesis 1: Career management effect employee career development in star-rated hotels in Bali. The results of the analysis showed career management variables (X1) on career development (Y1) acquisition of coefficients of 0.114 with a p-value of 0.000 smaller than 0.05. This acquisition shows that there is empirical evidence to accept the hypothesis that "Career management influences employee career development in star hotels in Bali". The acquisition of a positive coefficient of 0.114 indicates that career management will provide change and a positive relationship for employee career development in the future.

Hypothesis 2: Career competence effect employee career development in star-rated hotels in Bali. The results of the analysis show career management variables (X2) on career development (Y1) acquisition coefficient of 0.892 with a p-value of 0.000 smaller than 0.05 . This acquisition shows that there is empirical evidence to accept the hypothesis that "Career competence influences employee career development in star-rated hotels in Bali". The acquisition of a positive-signed coefficient of 0.892 indicates that career competency will provide changes and a positive relationship for employee career development in the future.

Hypothesis 3: Employee career development effect employee career satisfaction in star-rated hotels in Bali. The results of the analysis show career development variable (Y1) to career satisfaction (X3) acquisition coefficient of 0.780 with a $p$-value of 0.809 . This acquisition shows that there is empirical evidence to accept the hypothesis that "Career development of employees influences employee career satisfaction in star-rated hotels in Bali". The acquisition of a coefficient with a positive sign of 0.780 indicates that career development will provide changes and a positive relationship for employee career satisfaction in the future.

Hypothesis 4: Employee career satisfaction effect organizational commitment in star hotels in Bali. The results of the analysis show the variable career satisfaction (X3) on organizational commitment (X4) acquisition coefficient of 0.804 with a p-value of 0.609 . This acquisition shows that there is empirical evidence to accept the hypothesis that "employee career satisfaction influences organizational commitment in star hotels in Bali". The acquisition of a positive coefficient of 0.804 indicates that career satisfaction will give change and a positive relationship to employee organizational commitment going forward.

\section{CONCLUSION AND SUGGESTIONS}


From the results of this study it can be concluded that several things include:

- There is a positive significant influence of 0.114 between career management variables on employee career development, from these results it can be said that career management carried out really influences and has a positive impact on employee career development at Star Hotels in Bali;

- There is a positive significant influence of 0.829 between career competency variables on employee career development, which states that the career development of an employee is more likely to be influenced by employee career competency variables at Starred Hotels in Bali;

- There is a significant positive effect of 0.679 from the variable career development on employee career satisfaction. This indicates that career development programs carried out by the company have a good impact on employee career satisfaction at Star Hotels in Bali;

- There is a positive significant effect of 0.804 on employee career satisfaction on organizational commitment, this can mean employee career satisfaction has a significant impact on increasing employee organizational commitment at Star Hotels in Bali.

The suggestions that can be given as feedback in this study include:

- The need to empower and develop career management for employees by the company so that individual employees can measure themselves and evaluate themselves towards employee career development at good Star Hotels throughout Indonesia;

- Counseling and communication programs between employees need to be made with the aim of the company's attention to career competencies so that employee career development can run optimally;

- Study of employee career development needs to be carried out routinely by the company to obtain input on employee career satisfaction in the future;

- Organizational commitment is very important to be able to be fostered and improved, so that the role of the company is needed to be able to accommodate the desires of employees who want to develop and increase commitment and performance for the company.

Research Limitations. This study has several limitations and weaknesses that do come from researchers who are less serious, lack of research budget and lack of ability in quantitative analysis, so this research can be said to be far from perfect. Among others are:

- The use of research objects of Hotels in Badung Regency is considered to be less extensive in the scope of research objects which should use research objects, namely Hotels in all of Bali Province. This is caused by the limitations of researchers both in time, ability and research budget;

- Weaknesses of researchers in the ability of quantitative analysis have an impact on imperfect results, while a more up to date analysis tool can provide more perfect results.

\section{REFERENCES}

1. Brown. D., Brooks. L. Career choice and development: Applying contemporary theories to practice. San Francisco: Jossey-Bass

2. Burke, R.J., 2001. Managerial women's career experinces, satisfaction, well-being: a five country study. Cross Cultural Management.

3. Campion, M.A., Cheraskin, L., Stevens, M.J., 1994, Career-relaed antecentents and outcomes of job rotation. Academy of Management Journal.

4. Carson, K.D., Philips, J.S., Roe, C.W., 1996. A career entrenchment model: theoretical development and empirical outcomes. Journal of Career Development. 
5. Curry, J., Wakefield, D., Price, J and Mueller, C. 1986. On the Causal Ordering of Job Satisfaction and Organizational Commitment, Academy of Management Journal, Vol 29, No 4.

6. Dessler, Gary. 1997. Human Resource Management

7. Gaertner, K.N., 1989. Winning and losing: understanding managers reactions to strategic change. Human Relations.

8. Greenhaus, J.H., Parasuraman, S., Wormley, W.M., 1991. Effect of race on organization experiences, job performance evaluations and career outcomes. Academy of Management Journal.

9. Greenhaus. J. H., Callanan. G. A., Godshalk. V. M., 2010. Career Mangement 4th Edition. SAGE Publication, Inc. California, USA.

10. Igbaria, M., Wormley, W.M, 1991. Organizational experinces and career success of MIS professional and manager: an examination of race differences. MIS Quaterly.

11. Kong, Haiyan. 2011. Determinants and outcome of career competencies: Perpectives of hotel managers in China, Shandong University, China.

12. Kong, Haiyan. 2011. From hotel career management to employee's career satisfaction: The mediating effect of career competency, Shandong University, China.

13. Luthan, Fred. 2005. Organization Behavior, 10th Edition, McGraw-Hill Inc. USA.

14. Orpen, C., 1994. The effect of organizational and individual career management on career success. International Journal of Man Power, Vol. 4.

15. Simamora, Henry., 2004. Manajemen Sumber Daya Manusia, BP STIE YKPN, Yogyakarta.

16. Solimun., 2003. Structural Equation Modeling, LISTREL dan AMOS, Universitas Brawijaya, Malang.

17. Solimun., 2010. Partial Least Square PLS, Universitas Brawijaya, Malang.

18. Super, D.E., 1990. A life-span, life-space approach to career development.

19. Veldhoven, M. V and Dorenbosch.L., 2008. Age, proactivity and career development, Tilburg University, Netherlands.

20. Warta Warga, 2009. Definisi Kompetensi. Guna Dharma University. 